Volker Clausen and Bernd Hayo

\title{
MONETARY POLICY IN THE EURO AREA - LESSONS FROM THE FIRST YEARS
}

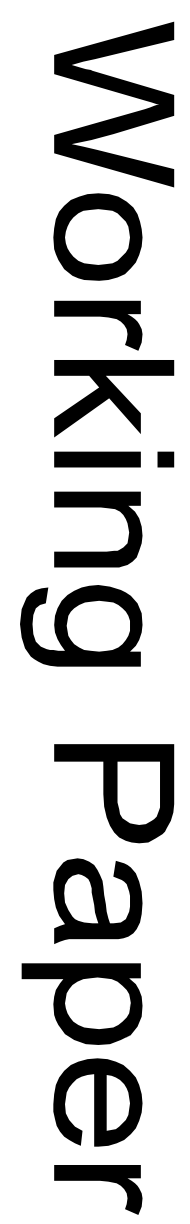




\title{
Monetary Policy in the Euro Area - Lessons from the First Years
}

\author{
Volker Clausen* and Bernd Hayo** \\ * University of Essen and Indiana University, Bloomington \\ ** University of Frankfurt, University of Essen, and ZEI, University of Bonn
}

May 2002

Volker Clausen

Department of Economics (FB 5)

University of Essen

D-45117 Essen

Germany

Tel: $\quad+49-201-183-3655$

Fax: +49-201-183-3974

Email:vvlausen@vwl.uni-essen.de

\author{
Bernd Hayo \\ Department of Economics \\ University of Frankfurt \\ D-60054 Frankfurt \\ Germany \\ Tel: $\quad+49-69-79828804$ \\ Fax: +49-69-79828933 \\ Email: hayo@wiwi.uni-frankfurt.de \\ (Corresponding author)
}

Thanks to participants of research seminars at the Universities of Bochum, Bonn, and Frankfurt/Main for helpful comments. Obviously, we are responsible for all remaining shortcomings. 


\title{
Monetary Policy in the Euro Area - Lessons from the First Years
}

\begin{abstract}
This paper investigates in a consistent semi-structural empirical framework three current issues of monetary policy in the euro area. First, regarding policy transmission we offer a three-stage procedure to combine the efficient estimation of economic structure prior to EMU with current ECB monetary policy. Second, we test whether the regime change leads - before or after - EMU to structural instability. Third, we investigate the stance of monetary policy in Europe. We compare a "counterfactual" ECB reaction function based on average interest rates prior to EMU with actual ECB policy. Furthermore, we compare actual ECB policy with interest rate projections using Bundesbank reaction functions and euroland data.
\end{abstract}

JEL-classification: E52, F41

Keywords: European Monetary Union, Monetary policy, Semi-structural modelling, Reaction function, Taylor rule, Transmission mechanism 


\section{Introduction}

Since the start of European Monetary Union (EMU) in 1999, three areas of empirical research in monetary economics increasingly attract interest: The most active line focuses on the transmission mechanism of monetary policy in the euro area because the effective conduct of European Central Bank (ECB) policy requires reliable information on the strength and the timing of the aggregate effects of monetary policy. Considerable attention is also paid to the differences in monetary policy transmission across the EMU member countries. A recent comprehensive survey is provided by Angeloni et al. (2002).

A second strand investigates whether the regime change in monetary policy caused a structural break in the underlying macroeconomic relationships. Before the start of EMU, some authors expected substantial changes (e.g. Arnold and De Vries, 2000). In this case, past data and empirical analyses cease to contain useful information on economic behaviour in the new monetary environment. This would seriously undermine the effective conduct of monetary policy in Europe. As one of the first studies in this area, Mihov (2001) also includes data after the establishment of EMU. Based on the accuracy of out-of sample forecasts for output and inflation in the euro area, he did not detect significant deviations and concludes that empirical research based on pre-EMU data continues to be relevant after the establishment of EMU.

A third upcoming line investigates the overall stance of ECB policy. In particular, how actual ECB policy relates to the previous behaviour of the Deutsche Bundesbank. ${ }^{1}$ Drawing on Clarida et al. (1998), Alesina et al. (2001) and Faust et al. (2001) apply an estimated reaction function of the Bundesbank to euroland data and compare the implied interest rate projections with actual ECB policy rates. Taking this benchmark, they find ECB rates to be consistently below those values that would have been chosen by the Bundesbank. Mihov (2001) finds that ECB behaviour resembles more an aggregate behaviour of the central banks in Germany, France and Italy than of the Bundesbank alone. ${ }^{2}$

This paper develops an empirical approach that is able to address in a consistent framework all three research strands simultaneously. We adopt a semi-structural modelling approach. It attempts to exploit the advantages of both, VAR and more structural models, while trying to

\footnotetext{
${ }^{1}$ Begg et al. (2002) compare the actual ECB policy with projections of Fed policy for the euro area. They apply a Taylor rule, which explains US interest rates, to euroland data and find that the Fed would have responded to the slowdown in Europe in 2001 in a similar quantitative dimension, but probably somewhat earlier.

${ }^{2}$ Aksoy et al. (2002) take a related, but somewhat different perspective. They analyse to which extent ECB interest rate setting based on euroland data differs from the interest rate setting being optimal only based on German data.
} 
avoid the well-known disadvantages. VAR models tend to be over-parameterised, rarely allow for informative cross-equation restrictions, and the test procedures tend to have low power. Structural models, on the other hand, impose numerous restrictions such that they often fail to capture the data generating process (DGP); in particular the underlying dynamics. Our combination of these data-led and theory-led approaches imposes sufficient restrictions to yield structurally meaningful equations, which are still admissible representations of the underlying data generating process.

We propose a three-stage modelling procedure in order to capture the specific context of EMU: In the first stage, we estimate in the period prior to EMU a system of nine equations. For each of the three largest EMU countries we specify an inflation equation, an output gap equation and a policy reaction function for interest rates. In the second stage, we hold the macroeconomic structure estimated in the first step constant and only estimate a single policy reaction function based on euro area aggregates. This allows us to model the changeover to EMU on the policy side assuming the economic structure to remain invariant. In the third stage, we study the impulse responses in the individual countries to a common interest rate shock.

Our specific set-up combines the efficient estimation of the pre-EMU economic structure with current ECB monetary policy making. Prior to EMU, the macroeconomic developments in the individual countries were affected by the national developments of interest rates and by the national effective exchange rates including the intra-European exchange rates. Therefore, these data ought to be used for an efficient estimation of the macroeconomic structure. After the establishment of EMU, however, we need to model introduction of a common monetary policy and the loss of the exchange rate channel between EMU members. Our semi-structural approach in conjunction with the three-stage modelling procedure exactly meets these requirements.

Our approach contributes to all three research strands mentioned above: First, we combine the pre-EMU economic structure with current ECB monetary policy making and analyse how interest rate shocks are transmitted across different EMU members. Our impulse responses illustrate the aggregate as well as the differential effects in euroland. Second, our econometric design allows for statistical tests for structural instability before and after the establishment of EMU. Our semi-structural approach enables us to exactly identify the equation(s) being subject to structural change. Third, we analyse ECB behaviour by estimating a "counterfactual" ECB reaction function based on past average interest rate data. We contrast our estimates with actual ECB rates to investigate how well this equation fits the data. 
Furthermore, we compare ECB interest rates with interest rate projections based on euroland data and Bundesbank reaction functions. Moving beyond previous studies in this research area, we perform direct statistical tests of the significance of observed differences between actual and projected interest rates.

The paper is organised as follows. Section 2 presents the econometric model. Section 3 analyses the counterfactual ECB reaction function based only on historical data prior to EMU. Section 4 compares the behaviour of the ECB and the Bundesbank. Section 5 concludes.

\section{Econometric model}

This section briefly outlines the underlying semi-structural model (see Clausen and Hayo 2002 for more details). We estimate a nine equation simultaneous equation model using fullinformation maximum likelihood techniques (FIML). The EMU in our model consists of France, Germany, and Italy, which together account for about $75 \%$ of total output in EMU. For each country, three equations are specified: an output gap, an inflation, and an interest rate equation. We use quarterly data from 1979:1, the start of the European Monetary System (EMS), to 2000:4, the most recent official data available to us. The data source are the IMF International Financial Statistics, and the actual estimation period is 1979:1 to 1996:4. We keep eight observations for out-of-sample tests before and after the establishment of EMU, respectively.

According to standard diagnostic tests for serial correlation, non-normality, and parameter stability, our model is an acceptable representation of the DGP. ${ }^{3}$ In addition, we perform an out-of-sample stability analysis. Again, we do not detect a problem with our specification (see Appendix, Table A). The Appendix also provides the FIML results for the output gap and inflation equations (Tables B and C). The labels F, G, and I represent France, Germany, and Italy, respectively. The short-term interest rate is denoted by Int, the output gap by Gap, the effective exchange rates by $E M U$ and $R O W$, and the inflation rate by Infl. All variables are quarter-to-quarter growth rates expressed in percent, except for the exchange rate, which is a four-period moving average of its natural logarithm.

In the output gap equations, the interest rate variables are found to be significantly negative but at different lags. The own lagged output gap is always significant. On the other hand, it is

\footnotetext{
${ }^{3}$ The estimations and statistical tests were performed with PC FIML 9.0. See Doornik and Hendry (1997) for a detailed description of the tests. We also computed robust standard errors (White 1980) to check for possible problems with heteroscedasticity. The corresponding test results are similar except for one case mentioned later in the text.
} 
hard to detect reliable international output spill-over effects. The same holds for the exchange rate effects, which are typically significant but often display opposite signs at different lags.

Table $\mathrm{C}$ in the Appendix presents the estimates for the inflation equations. In all countries, the output gap has a significant impact on inflation. In France, it is slightly above the $10 \%$ significance level but considerably lower when heteroscedasticity corrected standard errors are used (p-value: 0.079). The inflation dynamics are fairly similar with significant and similar coefficients occurring at the same lag length. ${ }^{4}$

Table 1 presents the estimates of the interest rate reaction functions. We make the conventional assumption that the inflation rate and the output gap enter the policy reaction function. Note that we employ the current values of these variables, which makes the system a true simultaneous equation model. Given the lags in statistical reporting, this amounts to a forward looking procedure in practice. We also allow for interest rate smoothing up to lag four. In a consistent testing-down process, we are able to reduce the number of lags to two. Persistence in interest rates is considerable, with own lags having a coefficient of at least 0.84 (France: 0.84, Germany: 0.89, Italy: 0.87). The German interest rate equation contains a constant term, which represents the "anchor" interest rate. In view of the interaction in the EMS, we include the German interest rate as an "anchor" in the French and Italian reaction functions. In the case of France, we find that the current German interest rate dominates the inclusion of an additional constant term. In the case of Italy, however, this EMS connection is weaker, which is consistent with economic experience. However, we keep this symmetric specification for the sake of comparability.

Table 1: FIML-system: Interest rate reaction functions

\begin{tabular}{lrr|lrr|lrr}
\hline France & Coeff. & S.E. & Germany $^{*}$ & Coeff. & S.E. & Italy & Coeff. $^{*}$ & S.E. \\
\hline FInt $_{\mathrm{t}-1}$ & $0.75^{* *}$ & 0.072 & GInt $_{\mathrm{t}-1}$ & $1.42^{* *}$ & 0.091 & IInt $_{\mathrm{t}-1}$ & $0.63^{* *}$ & 0.068 \\
FInt $_{\mathrm{t}-4}$ & $0.10^{(*)}$ & 0.049 & GInt $_{\mathrm{t}-2}$ & $-0.54^{* *}$ & 0.089 & IInt $_{\mathrm{t}-4}$ & $0.24^{* *}$ & 0.059 \\
\hline FGap $_{\mathrm{t}}$ & $0.27^{*}$ & 0.104 & GGap $_{\mathrm{t}}$ & 0.06 & 0.060 & IGap $_{\mathrm{t}}$ & $0.85^{* *}$ & 0.164 \\
\hline FInfl $_{\mathrm{t}}$ & $0.36^{*}$ & 0.145 & GInfl $_{\mathrm{t}}$ & $0.33^{*}$ & 0.148 & IInfl $_{\mathrm{t}}$ & $0.70^{* *}$ & 0.123 \\
\hline GInt $_{\mathrm{t}}$ & $0.13^{* *}$ & 0.054 & Constant & $0.46^{*}$ & 0.175 & GInt $_{\mathrm{t}-4}$ & 0.05 & 0.043 \\
\hline D81:2 & $4.09^{* *}$ & 0.745 & D91:1 & $1.16^{*}$ & 0.504 & D92:3 & $3.09^{* * *}$ & 0.651 \\
\hline$\sigma$ & 0.779 & & & 0.431 & & & 0.829 & \\
\hline
\end{tabular}

Notes: $(*), *, * *$ indicate statistical significance at a level of $10 \%, 5 \%$ and $1 \%$, respectively.

For France and Italy, we find that both, output gap and inflation, have a significant positive impact on interest rates. In Germany, the output gap does not have a significant influence on

\footnotetext{
${ }^{4}$ This conclusion is based here only on visual inspection. Clausen and Hayo (2002) perform a wide range of statistical tests for asymmetric monetary policy transmission in the EMU across the national output gap and inflation equations and across different time horizons.
} 
interest rates, while the coefficient on inflation is relatively large. Furthermore, a dummy capturing reunification is also included and found to be significant. Dummy variables for the other countries reflect the October 1981 realignment of the Franc and the EMS crisis in 1992. Since these events turned out to be insignificant in the German reaction function, this can be interpreted as further evidence of German dominance in the EMS (see, e.g., Wyplosz, 1989, von Hagen and Fratianni, 1990). Statistical tests based on the short-run coefficients confirm that Germany places the highest relative weight on inflation, followed by France and with Italy at the end of the spectrum. The implied long-run reaction functions further illustrate this result (Table 2). The Bundesbank reaction function places in comparison the greatest weight on inflation, followed by the Bancque de France and the Banca d'Italia.

Table 2: Long-run reaction functions

\begin{tabular}{llll}
\hline & Output gap & Inflation rate & Nominal "anchor" \\
\hline France & 1.73 & 2.28 & 3.26 \\
Germany & 0.49 & 2.89 & 4.02 \\
Italy & 2.46 & 2.02 & 0.48 \\
\hline
\end{tabular}

We checked our system for structural instability in the run-up to EMU. Using the out-ofsample observations from 1997:1 to 1998:4, Chow-tests do not indicate any instability. Thus, in the two years preceding EMU, no significant changes in economic behaviour can be observed.

\section{A counterfactual ECB reaction function}

Modelling EMU requires two modifications to the structure of our baseline model: First, the intra-EMU exchange rate channel is removed. Therefore, we now keep the nominal intraEMU effective exchange rate at its value in 1998:4. Second, monetary policy decision-making is transferred to the ECB. The national reaction functions and interest rates have to be replaced by a common reaction function and a European interest rate. In general, this reaction function may be assumed a priori or it can be estimated. In a first step, we estimate an EMU reaction function based on past average interest rates while restricting the rest of the system to the pre-EMU parameter estimates. Using this baseline model, we are then able to perform policy analyses conditional on a constant structure of the three economies.

We define aggregate EMU variables for the interest rate, inflation and the output gap based on weighted averages of national variables. The corresponding weights are the shares of national GDP in the aggregate GDP of the three countries in our sample (France: 0.304, Germany: 
0.451, Italy: 0.245). Estimating a single reaction function for the average European interest rate while keeping the parameters in the output gap and inflation equations fixed yields (standard errors in brackets):

EUInt $_{\mathrm{t}}=1.08$ EUInt $_{\mathrm{t}-1}-0.22$ EUInt $_{\mathrm{t}-2}+0.57+0.31$ EUInf $_{\mathrm{t}}+0.31 \mathrm{EUGap}_{\mathrm{t}}$
$(0.07)$
(0.18) (0.11)
$(0.06)$

+ 1.69 D81:2 + 0.67 D91:1 + 2.73 D92:3

$(0.33)$

The estimate for the interest rate smoothing parameter is 0.86 , which is within the range of estimates for the national reaction functions displayed in table 1. It is slightly lower than estimates by Clarida et al. (1998), who generally find values above 0.90 for the Fed, the Bundesbank, and the Bank of Japan. The policy weights on inflation and the output gap are identical. ${ }^{5}$ The dummies in $81: 2,91: 1$ and $92: 3$ are again related to realignments in the EMS and to German reunification.

The restricted pre-EMU part of the model is now combined with the estimated ECB reaction function to analyse the transmission of monetary policy in the euro area. The impulse responses in figure 1 illustrate the dynamic effects of an interest rate hike by one percentage point. As it is apparent from the first graph in the last row of figure 1, European interest rates (EUInt) need about eight quarters to gradually return to their initial value. In response, all three countries experience a decline in output and inflation (see first row of graphs in figure 1). The negative impact is strongest in Germany. It occurs after two quarters and vanishes after 10 quarters. In Italy, the trough occurs after six quarters and the output gap returns to normal after 12 quarters. In France, the minimum is found after seven quarters, while the economy needs 22 quarters to return to the original equilibrium. Statistical tests show that the reactions in Germany and Italy are indeed significantly stronger than in France (Clausen and Hayo, 2002).

The reaction of inflation follows the development of the output gaps (see second row in figure 1). The fall in inflation is strongest in Germany, followed by Italy and France. Germany also shows the earliest reaction, while the effect in France is weak, with its minimum occurring after four years. Moreover, persistence is much lower in Germany than in the other countries.

\footnotetext{
${ }^{5}$ This stands in contrast with most previous estimates of Taylor rules, see Clarida et al. (1998), Gerlach and Schnabel (2000) and Faust et al. (2001. Typically, the weight on the output gap is found to be comparatively smaller. This is generally explained by considerable uncertainty about the output gap.
} 
After 20 quarters, the pre-shock inflation rate is reached again. In the other countries, this adjustment requires about 48 quarters.

Finally, the last two graphs in figure 1 display the development of the aggregate EMU values resulting from the evolution of national values. The minimum output gap value occurs five periods after the shock. In other words, the maximum negative impact of a tightening of monetary policy takes place after less than one and a half years. European output needs less than three years to get back to its starting value. The maximum deflationary effect of monetary policy in the euro area can be observed six periods after the shock, thus lagging about one quarter behind output. The development of European prices is much more persistent, though.

Figure 1: Impulse responses to a one percentage point increase in ECB interest rates

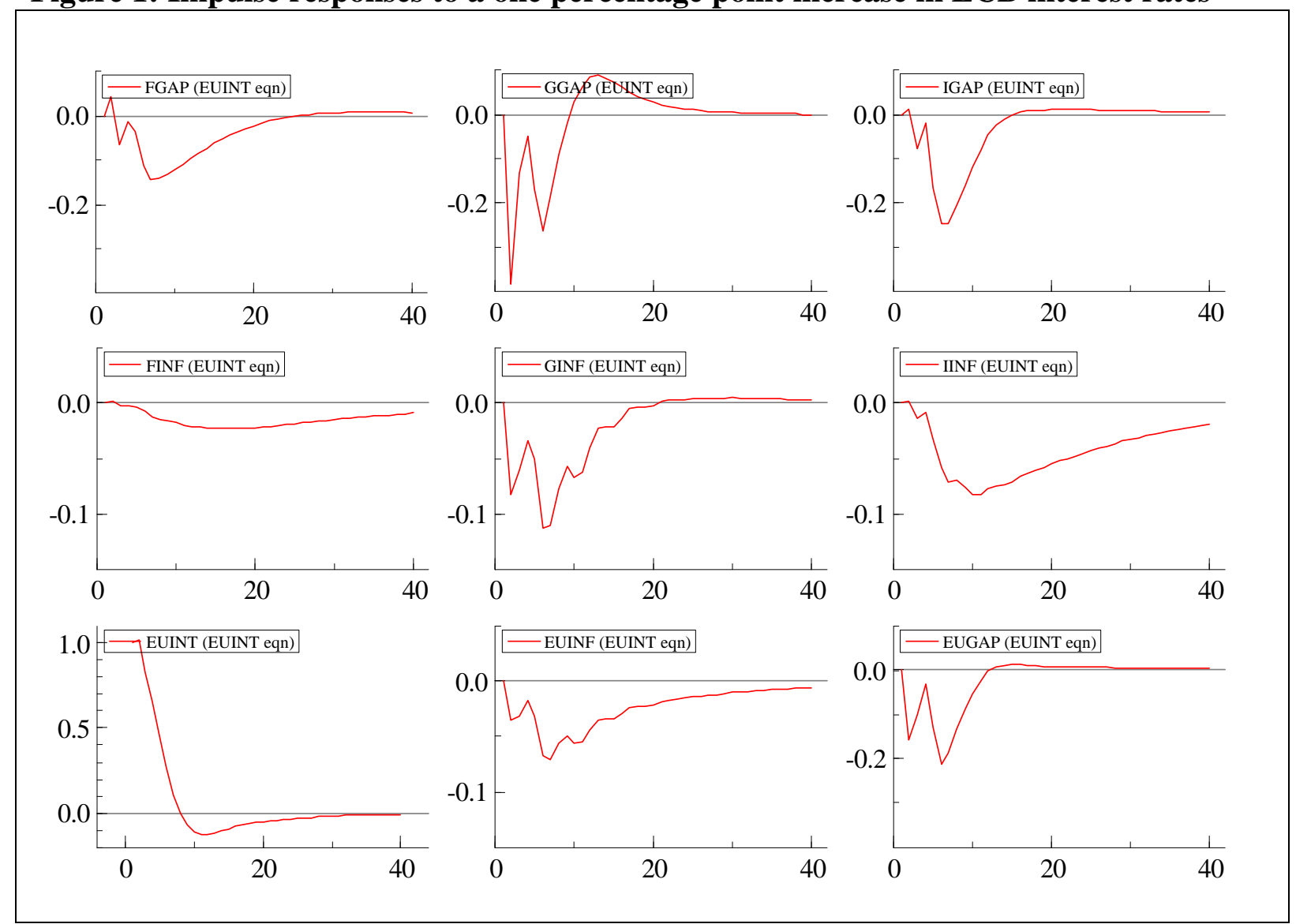

We check the stability of the system in order to detect potential structural changes in the runup to and after the start of EMU using 16 observations from 1997:1 to 2000:4. The conventional Chow test $(\mathrm{F}(112,65)=1.59 *)$ as well as the Chow test taking parameter uncertainty into account $(\mathrm{F}(112,65)=1.50 *)$ reject the null hypothesis of stability at a $5 \%$ level. However, this system instability is not due to the interest rate equation. Comparing onestep ahead forecasts with their 95\%-confidence intervals and actual values of EMU interest 
rates indicates that the observations are well within the corridor of statistical uncertainty (see figure 2).

Figure 2: Structural stability of "counterfactual” ECB reaction function

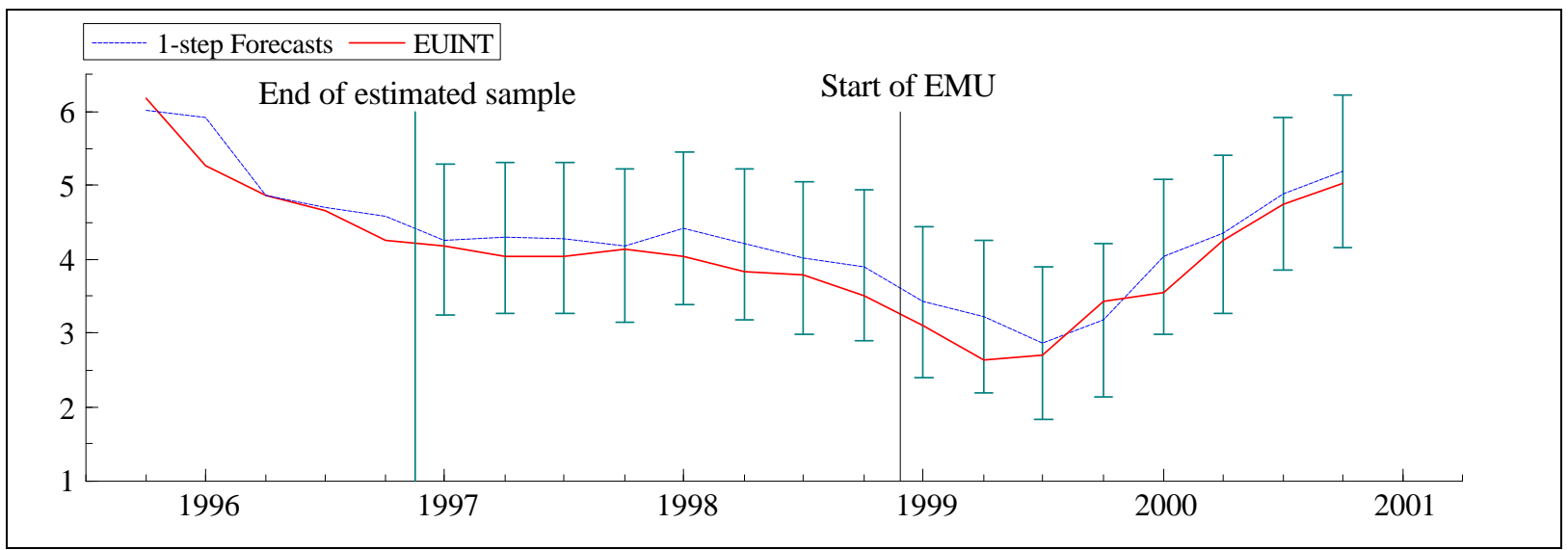

Mihov (2001) describes a similarly close tracking of actual values by his estimates as "remarkable". However, it must be noted that the equation is primarily driven by the interest smoothing parameter. Given the considerable persistence in interest rates, the actual influence of output gap and inflation weights on the overall fit of the equation is rather small.

In our model, the source of system instability lies in the Italian output gap equation. Figure 3 shows that our equation consistently overestimates the extent of the output gap. This suggests that the adjustment of the Italian economy during the early phase of EMU was associated with considerable costs in terms of lost real output. In absolute terms and ignoring estimation uncertainty, these costs amount to up to 2 percentage points of the output gap. Even more troubling, these costs do not seem temporary and to be growing over time. Note, however, that only the two observations in 2000:2 and 2000:4 actually fall outside the confidence intervals and, therefore, the output loss might in fact be lower.

Figure 3: Italian output gap equation under the EMU reaction function

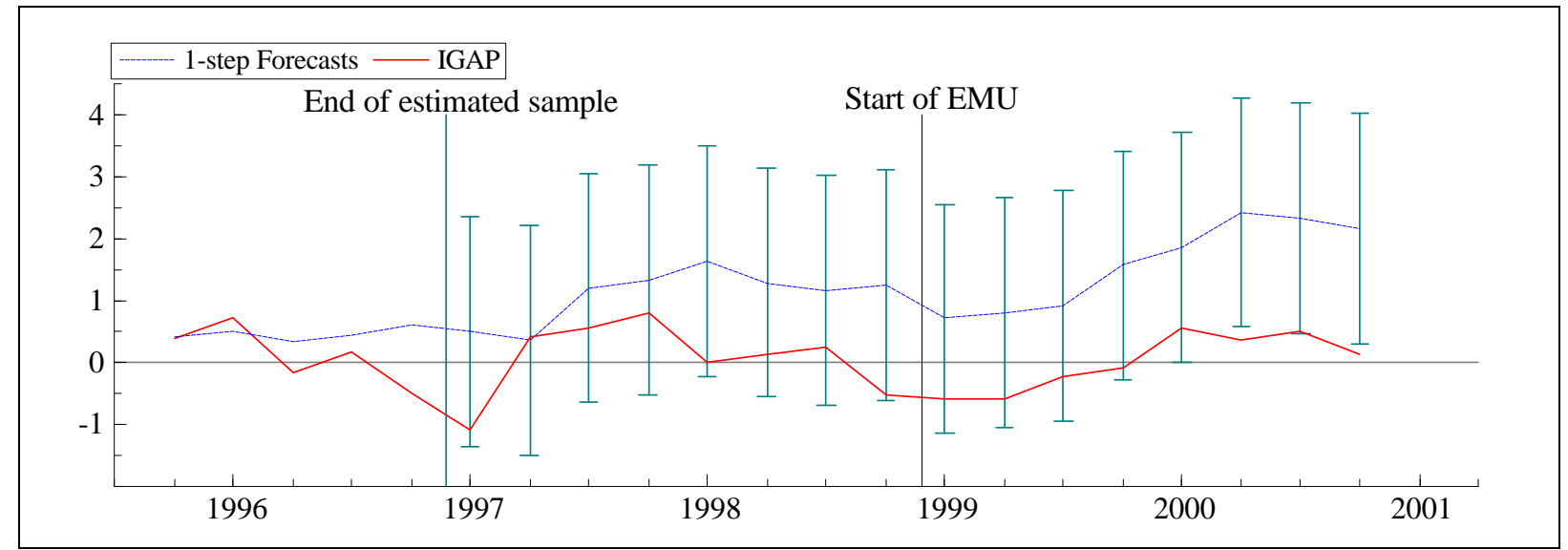


As indicated above, the focus on the actual interest rates versus the fitted values based on the short-run reaction function may be misleading, because the large coefficients of the lagged dependent variables are bound to generate a good fit of the series. Thus, in the following, we compare the actual interest rate with the target interest rate based on the long-run equilibrium. The static long-run is derived by replacing the lagged dependent variables and by setting the dummies to zero:

EUInt $=3.91+2.15$ EUInf +2.12 EUGap

Figure 4 compares the long-run target values with the average of the three interest rates over the 1990s. From 1999 onwards, actual ECB rates are used.

Figure 4: Comparison of actual interest rates with long-run target values

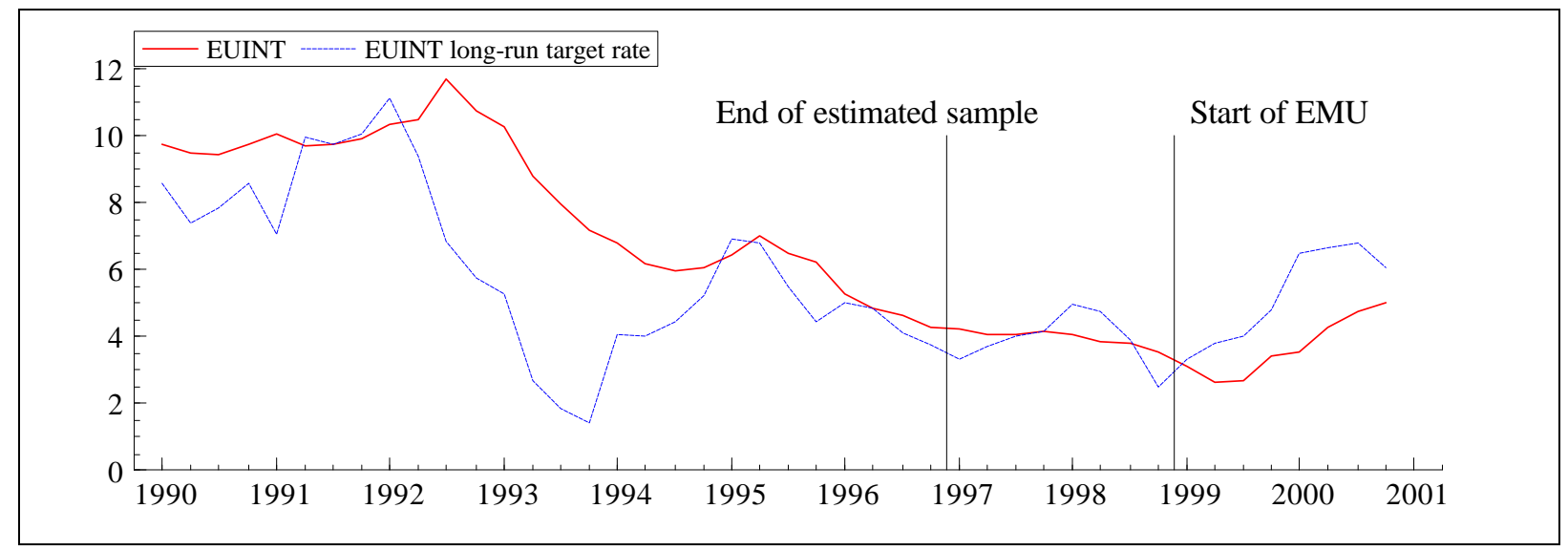

The long-run target rate is below the average interest rates from the early 80 s to early $90 \mathrm{~s}$. At the end of the period, however, long-run rates based on the estimated ECB reaction function suggest that actual interest rates are too low. This finding is analysed in more detail in the next section.

\section{The ECB as a Bundesbank Clone?}

It may be inappropriate to estimate a reaction function for the ECB based on an average of past interest rates of EMU member countries. The ECB is a new institution that has been specifically designed to conduct a monetary policy different from what most member countries' central banks have done in the past. In particular, it has been shaped after the Deutsche Bundesbank, one of the most stability-oriented central banks in the world. It is interesting now to ask whether the ECB has been successful in emulating the Bundesbank's monetary policy stance. 
Faust et al. (2001) compare the interest rates that would have been set if the Bundesbank were in charge of EMU monetary policy using a long-run Bundesbank reaction function based on the approach by Clarida et al. (1998). They find that interest rates actually set by the ECB tend to be below the projected Bundesbank rates. Evaluating various arguments that may explain this consistent deviation, they find that none is able to explain the gap between actual ECB interest rates and projected Bundesbank rates. Hence, in their view, the ECB has, at least so far, performed a relatively more expansionary monetary policy than the Bundesbank would have done.

We analyse the claim by Faust et al. (2001) in our framework. Keeping the output gap and inflation equations restricted to their pre-EMU specification, we implement the German longrun reaction function based on the estimates of table 3 as the interest rate function in the system.

$\mathrm{EUIntG}=0.49 \mathrm{EUGap}+2.89 \mathrm{EUInfl}+4.02$

The interest rate series consists of German rates until the start of EMU and ECB rates afterwards (EUIntG). Figure 5 compares one-step ahead forecasts with actual interest rates.

Figure 5: Comparing Bundesbank-based projected interest rates with actual ECB rates

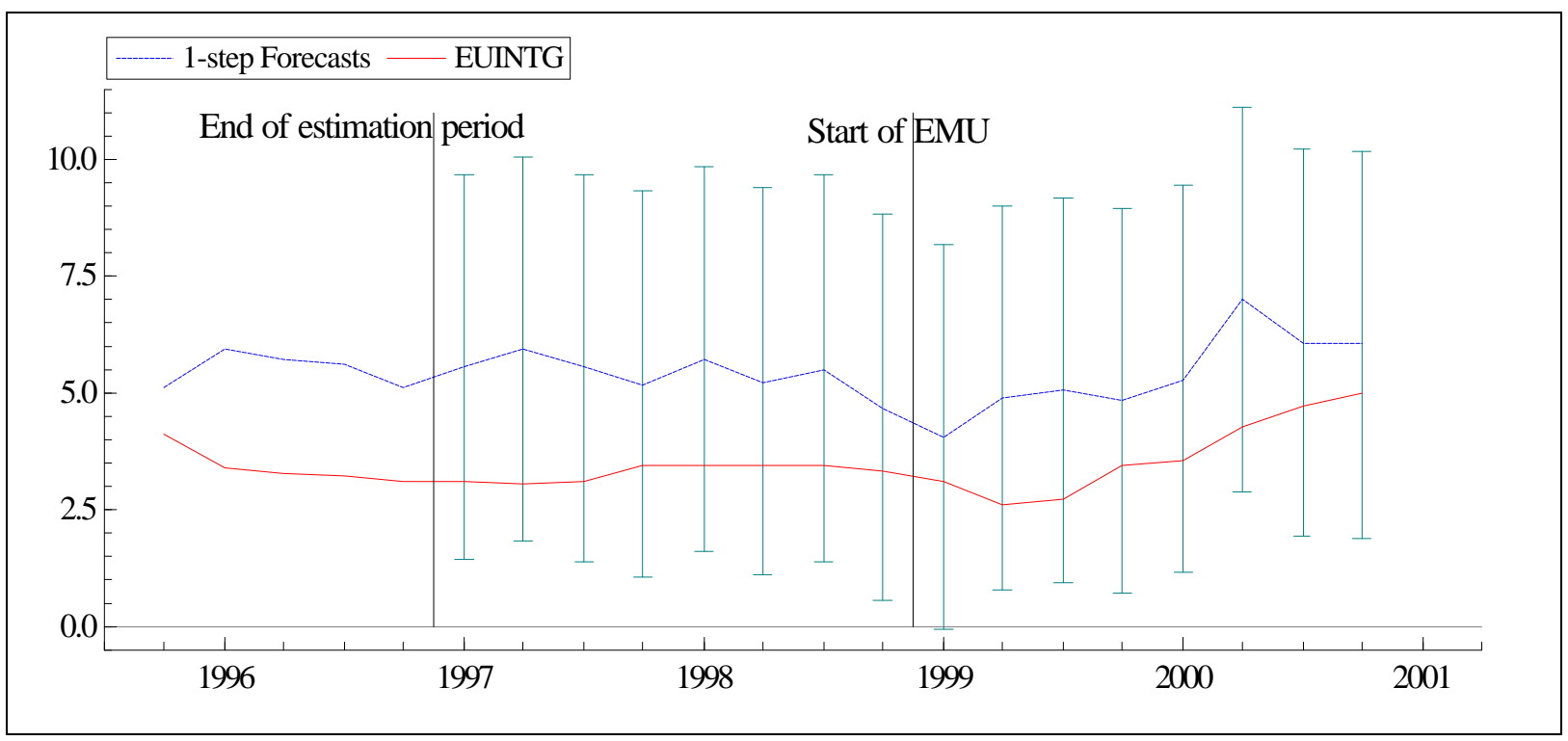

We also observe after the establishment of EMU that our projected Bundesbank interest rates are consistently higher than actual ECB interest rates. This confirms the finding by Faust et al. (2001). As indicated above, this outcome is also apparent from figure 4, which displays the long-run interest rate target for the estimated ECB reaction function based on past average 
interest rates. So even using an interest rate function based on average EMU member country interest rates we come to the same conclusion.

However, this outcome is not a direct consequence of the actual transferral of monetary policy to the ECB, as we obtain a very similar gap for the period 1996:1 to $1998: 4$. Hence, already in the run-up to EMU the Bundesbank departed from its long-run interest rate targets. If we accept that the ECB sets lower interest rates than those based on the German reaction function, then this is already part of the convergence process prior to EMU. In other words, no major structural change occurred after the hand-over of national monetary policy autonomy to the ECB. The transition is remarkably smooth.

On the other hand, it may be premature to accept the conclusion of a "softer" ECB based on a simple comparison of data points and projections. The projections are subject to uncertainty, which needs to be taken into account. Within our set-up, out-of-sample forecasting tests of the long-run reaction function can be used to assess whether the ECB interest rates are significantly lower than the projected Bundesbank rates. The confidence intervals in figure 5 around the one-step ahead forecasts indicate that the statistical uncertainty does not allow to discriminate between expected interest rates based on the Bundesbank reaction function and observed rates.

Finally, we compare our estimated long-run reaction function for Germany as a proxy for the ECB reaction function with a recent estimate by Faust et al. (2001), who use the same procedure as Clarida et al. (1998). Apparently, our estimated interest rate series in Figure 6 is in comparison much more volatile.

Figure 6: Comparison of long-run target interest rates with actual rates

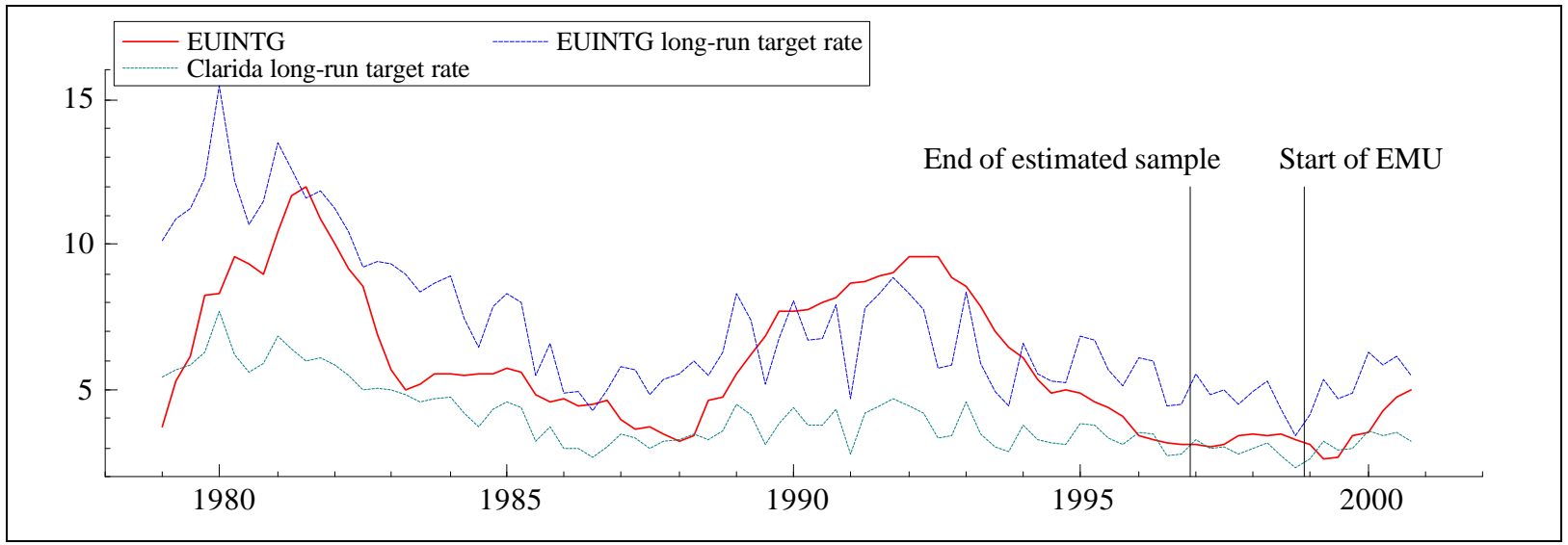

Notes: The actual interest rate series is the German short-term interest rate until the start of EMU and the official ECB money market rate afterwards. 
Further, our estimate is clearly superior in the earlier part of the sample period, while over the period 1995-1998, the other rule is closer to the actual interest rate series. However, at the end of the sample, the Clarida et al. (1998) rule fails to capture the rise in rates appropriately, while the our reaction function estimate performs clearly superior. ${ }^{6}$

Why is that the case? First, the Faust et al. and Clarida et al. estimates use higher frequency data. Given the non-availability of GDP data at monthly frequency, the authors had to resort to industrial production values. Second, their estimate is based on expected inflation as a variable in the short-run reaction function. Third, they rely on single-equation estimates. Fourth, the sample period slightly differs.

Checking the potential impact of these differences, we find the following: Results are somewhat sensitive to the estimation period, but we remain unable to replicate the Clarida et al. estimates. Estimating our reaction function in a single-equation context tends to widen the difference to the Clarida et al. estimates (the single-equation long-run estimate using German data is: GInt $=4.54+0.71$ GGap +2.65 GInfl). The way expected inflation rates are calculated is also an unlikely candidate for generating these differences. This leaves the use of industrial production and of monthly values as the most likely candidate for an explanation of the differences. Since the ECB ought to focus on overall GDP and not only on (volatile) industrial production, this raises doubts about the usefulness of the Clarida et al. specification for monetary policy. Moreover, higher frequency data do not have any obvious advantages with regard to long-run target values.

\section{Conclusions}

This paper provides new results on how monetary policy is transmitted in the three main EMU member countries, whether there was a notable structural break in response to the new monetary regime, and how actual ECB interest rate policy compares with interest rate projections based on estimated reaction functions for the euro area and for the Bundesbank. The underlying econometric model is quite powerful. The nine equation simultaneous equation system allows for a structural interpretation, but still passes standard diagnostic tests. The transition towards EMU is modelled as a change in the policy reaction function while keeping the remaining economic structure constant.

\footnotetext{
${ }^{6}$ Gerlach and Schnabel (2000) also provide estimates of a European Taylor rule using only data for the 1990s. The long-run form of their estimate is: EUInt $=1.58$ EUInf +0.45 EUGap +2.4 . This equation fits very well during the first year of EMU, but less well over the run-up to EMU. Moreover, it fails to capture the rise in interest rates in the year 2000 .
} 
We arrive at the following conclusions: First, regarding policy transmission, we found that an ECB monetary policy shock affects the German output gap most strongly, followed by Italy and France. The differences between Germany and Italy compared to France are statistically significant. Hence, we find asymmetric monetary policy effects over the short- and medium run. The differences are no longer significant over the long-run. European aggregate values also show the well-known hump-shaped responses to contractionary monetary policy shocks. The largest negative impact on the European output gap occurs after less than one and a half years. European Inflation is lagging behind by one period and is much more persistent than output.

Second, out-of-sample tests for structural stability suggest that in general the transmission mechanisms in Europe did not experience a structural break before or after the establishment of EMU. We explain this result by showing that the transition from the Bundesbank regime to the ECB was not accompanied by a structural break in the monetary regime. We do find, however, a break in the Italian output equation, which starts to significantly under-predict output gaps. This suggests that Italy's nominal and fiscal convergence prior to EMU resulted in non-trivial and lasting real output costs.

Third, comparing actual ECB interest rate policy with projections based on the European data and estimated Bundesbank reaction functions, we find the following: Using short-run estimates of reaction functions, ECB interest setting can be predicted quite accurately. This result, though, is more due to the high persistence of interest rates than to the explanatory power of the output gap and inflation rate. In our view, it is more informative to compare the long-run target values with actual ECB interest rates. During the early phase of EMU, ECB rates have been consistently below the long-run target rates derived from a Bundesbank reaction function. This gap emerged already three years before EMU was formed. It is not directly linked to the hand-over of monetary policy to the ECB. It might reflect some coordination of monetary policies between member countries before the official start of EMU. On the other hand, the conclusion derived from the perceived differences between ECB rates and projected long-run interest rates based on a Bundesbank reaction function, namely that the ECB is "softer" than the Bundesbank, may be premature. When calculating the long-run values, it is not taken into account that the statistical uncertainty associated with these estimates is much higher than for the underlying short-run estimates. Evaluating long-run standard errors indicates that the observed gap between these two interest rates is statistically not significant. Hence, more observations are needed to answer this question. This must be left for future research. 


\section{Appendix}

Table A: Diagnostics of the system

\begin{tabular}{|c|c|c|c|c|}
\hline & $\mathrm{AR}(2)$-test & Normality & Chow1-test & Chow2-test \\
\hline Vector statistics & $\mathrm{F}(162,276)=1.23$ & $\operatorname{Chi}^{2}(18)=22.08$ & $\mathrm{~F}(72,58)=1.51$ & $\mathrm{~F}(72,58)=1.22$ \\
\hline
\end{tabular}

Table B: FIML-system: Output gap equations

\begin{tabular}{|c|c|c|c|c|c|c|c|c|}
\hline France & Coeff. & S.E. & Germany & Coeff. & S.E. & Italy & Coeff. & S.E. \\
\hline FInt $_{\mathrm{t}-1}$ & 0.04 & 0.048 & GInt $_{t-1}$ & $-0.38^{(*)}$ & 0.206 & IInt $_{t-1}$ & 0.01 & 0.055 \\
\hline FInt $_{t-2}$ & $-0.14^{*}$ & 0.064 & GInt $_{t-2}$ & 0.48 & 0.299 & $\operatorname{IInt}_{\mathrm{t}-2}$ & -0.07 & 0.066 \\
\hline FInt $_{t-3}$ & 0.1 & 0.064 & GInt $_{t-3}$ & -0.17 & 0.258 & $\operatorname{IInt}_{\mathrm{t}-3}$ & 0.02 & 0.066 \\
\hline FInt $_{t-4}$ & -0.06 & 0.048 & GInt $_{t-4}$ & -0.14 & 0.168 & IInt $_{\mathrm{t}-4}$ & $-0.14^{* * *}$ & 0.052 \\
\hline $\mathrm{FGap}_{\mathrm{t}-1}$ & $0.63^{* * *}$ & 0.116 & $\mathrm{FGap}_{\mathrm{t}-1}$ & $-0.43^{(*)}$ & 0.232 & $\mathrm{FGap}_{\mathrm{t}-1}$ & -0.003 & 0.117 \\
\hline $\mathrm{FGap}_{\mathrm{t}-2}$ & 0.13 & 0.114 & $\mathrm{FGap}_{\mathrm{t}-2}$ & $0.42^{(*)}$ & 0.215 & $\mathrm{FGap}_{\mathrm{t}-2}$ & 0.12 & 0.116 \\
\hline GGap $_{t-1}$ & 0.001 & 0.060 & $\mathrm{GGap}_{\mathrm{t}-1}$ & $0.54^{* *}$ & 0.116 & GGap $_{\mathrm{t}-1}$ & 0.08 & 0.059 \\
\hline $\mathrm{GGap}_{\mathrm{t}-2}$ & $-0.14^{*}$ & 0.060 & $\mathrm{GGap}_{\mathrm{t}-2}$ & -0.01 & 0.111 & $\mathrm{GGap}_{\mathrm{t}-2}$ & $-0.15^{*}$ & 0.061 \\
\hline $\mathrm{IGap}_{\mathrm{t}-1}$ & $0.31^{*}$ & 0.121 & IGap $_{\mathrm{t}-1}$ & 0.26 & 0.230 & IGap $_{\mathrm{t}-1}$ & $0.46^{* *}$ & 0.126 \\
\hline $\mathrm{IGap}_{\mathrm{t}-2}$ & -0.11 & 0.114 & IGap $_{\mathrm{t}-2}$ & $-0.55^{*}$ & 0.219 & IGap $_{\mathrm{t}-2}$ & 0.01 & 0.114 \\
\hline FEMU $_{\mathrm{t}-2}$ & $-34.4^{* *}$ & 7.964 & GEMU $_{\mathrm{t}-2}$ & 1.69 & 0.412 & IEMU $_{\mathrm{t}-2}$ & $-23.2^{* * *}$ & 7.583 \\
\hline $\mathrm{FEMU}_{\mathrm{t}-3}$ & $37.2^{* *}$ & 8.029 & $\mathrm{GEMU}_{\mathrm{t}-3}$ & -16.6 & 13.04 & IEMU $_{\mathrm{t}-3}$ & $21.7^{* *}$ & 7.490 \\
\hline FROW $_{\mathrm{t}-2}$ & -8.22 & 11.82 & $\mathrm{GROW}_{\mathrm{t}-2}$ & 22.0 & 13.27 & IROW $_{t-2}$ & $19.7^{*}$ & 7.875 \\
\hline \multirow[t]{2}{*}{$\mathrm{FROW}_{\mathrm{t}-3}$} & 3.67 & 11.41 & GROW $_{\mathrm{t}-3}$ & -21.3 & 32.49 & $\mathrm{IROW}_{\mathrm{t}-3}$ & $-15.4^{*}$ & 7.905 \\
\hline & & & D90:1-93:1 & $12.7^{* * *}$ & 31.96 & & & \\
\hline$\sigma$ & 0.430 & & & 0.797 & & & 0.474 & \\
\hline
\end{tabular}

Notes: $(*), * * *$ indicate statistical significance at a level of $10 \%, 5 \%$ and $1 \%$, respectively.

Table C: FIML-system: Inflation rate equations ${ }^{7}$

\begin{tabular}{lrr|lrr|lrr}
\hline France & Coeff. & S.E. & Germany & Coeff. & S.E. & Italy & Coeff. & S.E. \\
\hline FInfl $_{\mathrm{t}-1}$ & $0.49^{* * *}$ & 0.064 & GInfl $_{\mathrm{t}-1}$ & $0.39^{* * *}$ & 0.073 & Infl $_{\mathrm{t}-1}$ & $0.33^{* *}$ & 0.077 \\
& & & & & & Infl $_{\mathrm{t}-3}$ & $0.18^{*}$ & 0.071 \\
FInfl $_{\mathrm{t}-4}$ & $0.43^{* *}$ & 0.058 & GInfl $_{\mathrm{t}-4}$ & $0.45^{* *}$ & 0.070 & IInfl $_{\mathrm{t}-4}$ & $0.40^{* *}$ & 0.083 \\
\hline FGap $_{\mathrm{t}}$ & 0.06 & 0.037 & GGap $_{\mathrm{t}}$ & $0.22^{* *}$ & 0.060 & IGap $_{\mathrm{t}}$ & $0.18^{*}$ & 0.071 \\
\hline D81:3 & $1.34^{* * *}$ & 0.267 & D91:1 & $-2.43^{* *}$ & 0.425 & & & \\
D82:3 & $-2.23^{* *}$ & 0.270 & & & & & & \\
D87:1 & $0.82^{* *}$ & 0.260 & & & & & & \\
\hline$\sigma$ & 0.296 & & & 0.573 & & & 0.487 & \\
\hline
\end{tabular}

Notes: $(*), *, * *$ indicate statistical significance at a level of $10 \%, 5 \%$ and $1 \%$, respectively.

\footnotetext{
${ }^{7}$ Several impulse dummies in the French inflation equation capture outliers. The French Franc was devalued against the DM on 5 October 1981 by $8.8 \%$, 14 June 1982 by $10.6 \%$, and 12 January 1987 by $3 \%$. In the case of Germany, we need one dummy to capture the reunification. The inclusion of oil prices in the inflation equations in order to account for import price shocks did not change this picture. The corresponding results are omitted for the sake of parsimony of our model.
} 


\section{References}

Aksoy, Y., P. De Grauwe, and H. Dewachter (2002), Do Asymmetries Matter for European Monetary Policy?, European Economic Review 46, 443-469.

Alesina, A., O. J. Blanchard, J. Gali, F. Giavazzi, and H. Uhlig (2001), Defining a Macroeconomic Framework for the Euro Area, Monitoring the ECB 3, London: CEPR.

Angeloni, I., A. Kashyap, B. Mojon, and D. Terlizzese (2002), Monetary Transmission in the Euro Area: Where Do We Stand?, ECB Working Paper 114, January.

Arnold, I.J.M. and C.G. de Vries (2000), Endogenous Financial Structure and the Transmission of ECB Policy, in: J. von Hagen, C.J. Waller (eds.), Regional Aspects of Monetary Policy in Europe, Boston: Kluwer, 193-218.

Begg, D., F. Canova, P. De Grauwe, A. Fatas and P. Lane (2002), Surviving the Slowdown Monitoring the ECB 4, London: CEPR.

Clarida, R., J. Gali, and M. Gertler (1998), Monetary Policy Rules in Practice, European Economic Review 42, 1033-1067.

Clausen, V. and B. Hayo (2002), Asymmetric Monetary Policy Effects in EMU, ZEI Working Paper 4, March.

Doornik, J. and D.F. Hendry (1997), Modelling Dynamic Systems Using PcFIML 9.0, London: International Thomson Business Press.

Faust, J., J.H. Rogers, and J.H. Wright (2001), An Empirical Comparison of Bundesbank and ECB Monetary Policy Rules, Board of Governors, International Finance Discussion Paper No. 705, August.

Gerlach, S. and G. Schnabel (2000), The Taylor Rule and Interest Rates in the EMU area, Economics Letters 67, 165-171.

Mihov, I. (2001), Monetary Policy Implementation and Transmission in the European Monetary Union, Economic Policy 16, October, 369-406.

Von Hagen, J. and M. Fratianni (1990), German Dominance in the EMS: Evidence from Interest Rates, Journal of International Money and Finance 9, 358-375.

White, H. (1980), A Heteroscedasticity-Consistent Covariance Matrix Estimator and a Direct Test for Heteroscedasticity, Econometrica 48, 817-838.

Wyplosz, C.A. (1989), Asymmetry in the EMS: Intentional or Systemic?, European Economic Review 33, 310-320. 


\section{ZEI Papers}

ZEI Policy Paper B97-01

ZEI Policy Paper B97-02

ZEI Policy Paper B97-03

ZEI Policy Paper B97-04

ZEI Policy Paper B98-01

ZEI Policy Paper B98-02

ZEI Policy Paper B98-03

ZEI Policy Paper B98-04

ZEI Policy Paper B98-05

ZEI Policy Paper B98-06

ZEI Policy Paper B98-07

ZEI Working Paper B98-08

ZEI Working Paper B98-09

ZEI Policy Paper B98-10
A Stability Pact for Europe (a Forum organized by ZEI) Employment and EMU (Deutsch-Französisches Wirtschaftspolitisches Forum/ Forum Economique Franco-Allemand)

Liberalising European Markets for Energy and Telecommunications: Some Lessons from the US Electric Utility Industry (Tom Lyon and John Mayo) Macroeconomic Stabilization with a Common Currency: Does European Monetary Unification Create a Need for Fiscal Insurance or Federalism? (Kenneth Kletzer) Budgeting Institutions for Aggregate Fiscal Discipline (Jürgen von Hagen)

Trade with Low-Wage Countries and Wage Inequality (Jaleel Ahmad)

Central Bank Policy in a More Perfect Financial System (Jürgen von Hagen and Ingo Fender)

The EMU`s Exchange Rate Policy (DeutschFranzösisches Wirtschaftspolitisches Forum/ Forum Economique Franco-Allemand)

Estimating a European Demand for Money (Bernd Hayo)

Monetary Union, Asymmetric Productivity Shocks and Fiscal Insurance: an Analytical Discussion of Welfare Issues (Kenneth M. Kletzer)

Designing Voluntary Environmental Agreements in Europe: Some Lessons from the U.S. EPA`s 33/50 Program (John W. Maxwell) Money-Output Granger Causality Revisited: An Empirical Analysis of EU Countries (Bernd Hayo) US Monetary Policy AND Monetary Policy and the ESCB (Robert L. Hetzel)

Der Wettbewerb der Rechts- und politischen Systeme in der Europäischen Union (Martin Seidel) 
ZEI Working Paper B98-11

ZEI Policy Paper B98-11A

ZEI Working Paper B98-12

ZEI Working Paper B98-13

ZEI Working Paper B98-14

ZEI Working Paper B98-15

ZEI Policy Paper B98-16

ZEI Working Paper B99-01

ZEI Working Paper B99-02

ZEI Working Paper B99-03

ZEI Working Paper B99-04

ZEI Working Paper B99-05

ZEI Working Paper B99-06
Exchange Rate Regimes in the Transition Economies: Case Study of the Czech Republic: 1990-1997 (Julius Horvath)

Die Bewertung der „, dauerhaft tragbaren öffentlichen Finanzlage" der EU Mitgliedstaaten beim Übergang zur dritten Stufe der EWWU (Rolf Strauch)

Price Stability and Monetary Policy Effectiveness when Nominal Interest Rates are Bounded at Zero (Athanasios Orphanides and Volker Wieland) Fiscal Policy and Intranational Risk-Sharing (Jürgen von Hagen)

Free Trade and Arms Races: Some Thoughts Regarding EU-Russian Trade (Rafael Reuveny and John Maxwell)

Can Taxing Foreign Competition Harm the Domestic Industry? (Stefan Lutz)

Labour Market \& Tax Policy in the EMU (DeutschFranzösisches Wirtschaftspolitisches Forum/ Forum Economique Franco-Allemand)

The Excess Volatility of Foreign Exchange Rates:

Statistical Puzzle or Theoretical Artifact? (Robert B.H. Hauswald)

The Consequences of Labour Market Flexibility: Panel Evidence Based on Survey Data (Rafael Di Tella and Robert MacCulloch)

The Macroeconomics of Happiness (Rafael Di Tella, Robert MacCulloch and Andrew J. Oswald)

The Finance-Investment Link in a Transition Economy: Evidence for Poland from Panel Data (Christian Weller) Tumbling Giant: Germany`s Experience with the Maastricht Fiscal Criteria (Jürgen von Hagen and Rolf Strauch)

Productivity Convergence and Economic Growth: A Frontier Production Function Approach (Christopher M. Cornwell and Jens-Uwe Wächter) 
ZEI Working Paper B99-07

ZEI Working Paper B99-08

ZEI Working Paper B99-09

ZEI Working Paper B99-10

ZEI Policy Paper B99-11

ZEI Working Paper B99-12

ZEI Working Paper B99-13

ZEI Working Paper B99-14

ZEI Working Paper B99-15

ZEI Working Paper B99-16

ZEI Working Paper B99-17

ZEI Working Paper B99-18

ZEI Working Paper B99-19

ZEI Working Paper B99-20
Comovement and Catch-up in Productivity Across

Sectors: Evidence from the OECD (Christopher M.

Cornwell and Jens-Uwe Wächter)

The Connection Between More Multinational Banks and Less Real Credit in Transition Economies (Christian Weller)

Monetary Policy, Parameter Uncertainty and Optimal Learning (Volker Wieland)

Financial Liberalization, Multinational Banks and Credit Supply: the Case of Poland (Christian Weller)

Financial Supervision and Policy Coordination in the EMU (Deutsch-Französisches Wirtschaftspolitisches Forum / Forum Economique Franco-Allemand) Size Distortions of Tests of the Null Hypothesis of Stationarity: Evidence and Implications for Applied Work (Mehmet Caner and Lutz Kilian)

Financial Fragility or What Went Right and What Could Go Wrong in Central European Banking? (Christian E. Weller and Jürgen von Hagen) Industry Effects of Monetary Policy in Germany (Bernd Hayo and Birgit Uhlenbrock)

Financial Crises after Financial Liberalization:

Exceptional Circumstances or Structural Weakness?

(Christian E. Weller)

Multinational Banks and Development Finance (Christian E. Weller and Mark J. Scher)

Stability of Monetary Unions: Lessons from the Breakup of Czechoslovakia (Jan Fidrmuc, Julius Horvath and Jarko Fidrmuc)

Why are Eastern Europe`s Banks not failing when everybody else`s are? (Christian E. Weller and Bernard Morzuch)

The Evolution of Monetary Policy in Transition Economies (Ali M. Kutan and Josef C. Brada) Subnational Government Bailouts in Germany (Helmut Seitz) 
ZEI Working Paper B99-21

ZEI Working Paper B99-22

ZEI Working Paper B99-23

ZEI Working Paper B99-24

ZEI Working Paper B99-25

ZEI Working Paper B99-26

ZEI Working Paper B00-01

ZEI Working Paper B00-02

ZEI Working Paper B00-03

ZEI Policy Paper B00-04

ZEI Working Paper B00-05

ZEI Working Paper B00-06

ZEI Policy Paper B00-07

ZEI Working Paper B00-08

ZEI Working Paper B00-09

ZEI Working Paper B00-10
The End of Moderate Inflation in Three Transition Economies? (Josef C. Brada and Ali M. Kutan)

Partisan Social Happiness (Rafael Di Tella and Robert MacCulloch)

Informal Family Insurance and the Design of the Welfare State (Rafael Di Tella and Robert MacCulloch)

What Makes a Revolution? (Robert MacCulloch)

Micro and Macro Determinants of Public Support for Market Reforms in Eastern Europe (Bernd Hayo)

Skills, Labour Costs, and Vertically Differentiated Industries: a General Equilibrium Analysis (Stefan Lutz and Alessandro Turrini)

Monetary Union and Fiscal Federalism (Kenneth Kletzer and Jürgen von Hagen)

Inflation Bias and Productivity Shocks in Transition Economies: The Case of the Czech Republic (Josef C. Brada, Arthur E. King and Ali M. Kutan) Integration, Disintegration and Trade in Europe: Evolution of Trade Relations During the 1990`s (Jarko Fidrmuc and Jan Fidrmuc)

A New Political Culture in the EU - Democratic Accountability of the ECB (Christa Randzio-Plath)

Liberalization, Democracy and Economic Performance during Transition (Jan Fidrmuc)

The Demand for Money in Austria (Bernd Hayo)

EMU and Economic Growth in Europe (DeutschFranzösisches Wirtschaftspolitisches Forum / Forum Economique Franco-Allemand)

The Effectiveness of Self-Protection Policies for Safeguarding Emerging Market Economies from Crises (Kenneth Kletzer)

Rational Institutions Yield Hysteresis (Rafael Di Tella and Robert MacCulloch)

The Importance of Domestic Political Institutions: Why and How Belgium and Italy qualified for EMU (Mark Hallerberg) 
ZEI Working Paper B00-11

ZEI Policy Paper B00-12

ZEI Working Paper B00-13

ZEI Working Paper B00-14

ZEI Working Paper B00-15

ZEI Policy Paper B00-16

ZEI Policy Paper B00-17

ZEI Working Paper B00-18

ZEI Working Paper B00-19

ZEI Working Paper B00-20

ZEI Working Paper B01-01

ZEI Working Paper B01-02

ZEI Working Paper B01-03

ZEI Working Paper B01-04
A Dynamic Approach to Inflation Targeting in Transition Economies (Lucjan T. Orlowski)

Rechtsetzung und Rechtsangleichung als Folge der einheitlichen europäischen Währung (Martin Seidel)

Back to the Future: The Growth Prospects of Transition Economies Reconsidered (Nauro F. Campos)

Sources of Real Exchange Rate Fluctuations in Transition Economies: The Case of Poland and Hungary (Selahattin Dibooglu and Ali M. Kutan) Regional Risksharing and Redistribution in the German Federation (Jürgen von Hagen and Ralf Hepp)

The European Central Bank: Independence and Accountability (Christa Randzio-Plath and Tomasso Padoa-Schioppa)

Rückführung der Landwirtschaftspolitik in die Verantwortung der Mitgliedsstaaten? - Rechts- und Verfassungsfragen des Gemeinschaftsrechts (Martin Seidel)

Budget Processes: Theory and Experimental Evidence (Karl-Martin Ehrhart, Roy Gardner, Jürgen v. Hagen and Claudia Keser)

Income Dynamics and Stability in the Transition Process - General Reflections applied to the Czech Republic (Jens Hölscher)

Breaking-Up a Nation, from the Inside (Etienne Farvaque)

Divided Boards: Partisanship through Delegated Monetary Policy (Etienne Farvaque, Gaël Lagadec) The Konstanz Seminar on Monetary Theory and Policy at Thirty (Michele Fratianni, Jürgen von Hagen) Preferences over Inflation and Unemployment: Evidence from Surveys of Happiness (Rafael di Tella, Robert J. MacCulloch and Andrew J. Oswald) The Determination of Umemployment Benefits (Rafael di Tella and Robert J. MacCulloch) 
ZEI-Policy Paper B01-05

ZEI Working Paper B01-06

ZEI Working Paper B01-07

ZEI Working Paper B01-08

ZEI Working Paper B01-09

ZEI Working Paper B01-10

ZEI Working Paper B01-11

ZEI Policy Paper B01-12

ZEI Working Paper B01-13

ZEI Working Paper B01-14

ZEI Working Paper B01-15

ZEI Working Paper B01-16
Trade Rules and Global Governance: A Long Term

Agenda / The Future of Banking (Deutsch-

Französisches Wirtschaftspolitisches Forum/ Forum

Economique Franco-Allemand)

Opposites Attract: The Case of Greek and Turkish

Financial Markets (Konstantinos Drakos and Ali M.

Kutan)

The Convergence of Monetary Policy between

Candidate Countries and the European Union (Josef C.

Brada and Ali M. Kutan)

The Functioning of Economic Policy Coordination (Jürgen von Hagen and Susanne Mundschenk)

Democracy in Transition Economies: Grease or Sand in the Wheels of Growth? (Jan Fidrmuc)

Integration of the Baltic States into the EU and Institutions of Fiscal Convergence: A Critical Evaluation of Key Issues and Empirical Evidence (Ali M. Kutan and Niina Pautola-Mol)

Inflationary Performance in a Monetary Union with Large Wage Setters (Lilia Cavallari)

The Impact of Eastern Enlargement on EU-Labour Markets / Pensions Reform Between Economic and Political Problems (Deutsch-Französisches

Wirtschaftspolitisches Forum/Forum Economique Franco-Allemand)

German Public Finances: Recent Experiences and Future Challenges (Jürgen von Hagen und Rolf $R$. Strauch)

Formal Fiscal Restraints and Budget Processes as Solutions to a Deficit and Spending Bias in Public Finances - U.S. Experience and Possible Lessons for EMU (Rolf Strauch and Jürgen von Hagen)

Programs without Alternative: Public Pensions in the OECD (Christian E. Weller)

Sources of Inflation and Output Fluctuations in Poland and Hungary: Implications for Full Membership in the European Union (Selahattin Dibooglu and Ali M. Kutan) 
ZEI Working Paper B01-17

ZEI Working Paper B01-18

ZEI Working Paper B01-19

ZEI Working Paper B01-20

ZEI Working Paper B01-21

ZEI Working Paper B01-22

ZEI Working Paper B01-23

ZEI Working Paper B01-24

ZEI Working Paper B01-25

ZEI Working Paper B01-26

ZEI Working Paper B01-27

ZEI Policy Paper B01-28
Executive Authority, the Personal Vote, and Budget Discipline in Latin American and Carribean Countries (Mark Hallerberg and Patrick Marier) Monetary Policy in Unknown Territory The European Central Bank in the Early Years (Jürgen von Hagen and Matthias Brückner)

Detrending and the Money-Output Link: International Evidence (R.W. Hafer and Ali M. Kutan)

An Empirical Inquiry of the Efficiency of Intergovernmental Transfers for Water Projects based on the WRDA Data (Anna Rubinchik-Pessach)

Balkan and Mediterranean Candidates for European Union Membership: The Convergence of their Monetary Policy with that of the European Central Bank (Josef C. Brada and Ali M. Kutan)

Strategic Delegation and International Capital Taxation (Matthias Brückner)

Migration and Adjustment to Shocks in Transition Economies (Jan Fidrmuc)

Disintegration and Trade (Jarko and Jan Fidrmuc) Monetary Convergence of the EU Candidates to the Euro: A Theoretical Framework and Policy Implications (Lucjan T. Orlowski)

Regional Effects of Terrorism on Tourism: Evidence from Three Mediterranean Countries (Konstantinos Drakos and Ali M. Kutan) Investor Panic, IMF Actions, and Emerging Stock Market Returns and Volatility: A Panel Investigation (Bernd Hayo and Ali M. Kutan)

Political Economy of the Nice Treaty: Rebalancing the EU Council / The Future of European Agricultural Policies (Forum Economique FrancoAllemand / Deutsch-Französisches Wirtschaftspolitisches Forum) 
ZEI Working Paper 01-29

ZEI Working Paper B02-01

ZEI Working Paper B02-02

ZEI Working Paper B02-03

ZEI Working Paper B02-04

ZEI Working Paper B02-05

ZEI Working Paper B02-06

ZEI Working Paper B02-07

ZEI Working Paper B02-08

ZEI Working Paper B02-09
Is Kazakhstan vulnerable to the Dutch Disease? (Karlygash Karalbayeva, Ali M. Kutan and Michael L. Wyzan)

Does Inflation Targeting Matter? (Manfred J.M. Neumann and Jürgen von Hagen)

The Euro System and the Federal Reserve System Compared: Facts and Challenges (Karlheinz Ruckriegel and Franz Seitz)

The Choice of Exchange Rate Systems: An Empirical Analysis for Transition Economies (Jürgen von Hagen and Jizhong Zhou) Asymmetric Monetary Policy Effects in EMU (Volker Clausen and Bernd Hayo) Real and Monetary Convergence Within the European Union and Between the European Union and Candidate Countries: A Rolling Cointegration Approach (Josef C. Brada, Ali M. Kutan and Su Zhou)

Is there Asymmetry in Forward Exchange Rate Bias? Multi-Country Evidence (Su Zhou and Ali M. Kutan)

Perspektiven der Erweiterung der Europäischen Union (Martin Seidel)

Has the Link between the Spot and Forward Exchange Rates Broken Down? Evidence from Rolling Cointegration Tests (Ali M. Kutan and Su Zhou)

Monetary Policy in the Euro Area - Lessons from the First Years (Volker Clausen and Bernd Hayo) 